\title{
Türkiye'de Doğrudan Yabancı Yatırımlar, Karbon Emisyonu ve İktisadi Büyüme: Veriye Dayalı Bir Analiz
}

Araştırma Makalesi /Research Article

Muhammed BENLİ ${ }^{1}$

ÖZ: Doğrudan yabancı yatırımların ülkelerin kalkınmalarında oynadı̆̆ önemli rolün ötesinde, literatürde üzerinde sıkça durulan bir diğer konu ise, doğrudan yabancı yatırımların enerji tüketimi üzerindeki etkisi ve çevresel sonuçlarıdır. Bu çalışmada, 1974 - 2014 dönemi için Türkiye'de doğrudan yabancı yatırımlar, karbon emisyonu, enerji tüketimi, ekonomik büyüme ve bazı diğer ekonomik değişkenler arasındaki tümevarımlı nedensel çıkarım şablonlarl, Yönlendirilmiş Döngüsüz Graflar (DAGs) metodu kullanllarak incelenmiştir. Böylece çalışmada, değişkenler arasındaki dolaylı ve dolaysız nedenselliklerin ve doğrudan yabancı yatırımların çevresel etkilerinin ortaya konulması amaçlanmıştır. Elde edilen DAGs şablonları, doğrudan yabancl yatırımların dolayl olarak dış ticaret üzerinden karbon emisyonlarını tetiklediğini, karbon emisyonları ve enerji tüketiminin ise ekonomik büyümeyi takip ettiğini ortaya koymaktadır. DAG şablonları ayrıca, kirliliğin, enerji tüketiminin doğrudan bir belirleyicisi olduğunu göstermektedir.

Anahtar Kelimeler: Doğrudan Yabancı Yatırım, $\mathrm{CO}_{2}$ Emisyonu, Yönlendirilmiş Döngüsüz Graflar

JEL Kodları: F18, F64, C60

\section{Foreign Direct Investment, Carbon Emission and Economic Growth in Turkey: A Data Driven Analysis}

\begin{abstract}
Beyond the important role of foreign direct investments in the development of countries, the impact of foreign direct investment on energy consumption and its environmental consequences are also of interest in the literature. In this study, we empirically examine the causal patterns among foreign direct investment, $\mathrm{CO}_{2}$ emissions, economic growth, and some other economic factors in Turkey for the period 1974 - 2014 using Directed Acyclic Graphs (DAGs). In doing so, in this study, we attempt to shed light on both the direct and indirect causation between these factors and the environmental effects of foreign direct investment. The resulting DAG patterns suggest that foreign direct investment has an indirect effect on $\mathrm{CO}_{2}$ emissions through an intermediate variable, trade, whereas both carbon emissions and energy consumption follows economic growth. The DAGs pattern also signifies that pollution is a significant determinant of energy consumption.
\end{abstract}

Keywords: Foreign Direct Investment, $\mathrm{CO}_{2}$ Emission, Directed Acyclic Graphs JEL Codes: F18, F64, C60

\footnotetext{
${ }^{1}$ Dr. Öğr. Üye., Bilecik Şeyh Edebali Üniversitesi, İİBF, İktisat Bölümü, muhammed.benli@bilecik.edu.tr, orcid.org/0000-0001-6486-8739
} 


\section{Giriş}

Doğrudan yabancı sermaye yatırımları, sermayenin ev sahibi ülkelere girişiyle yeni iş imkanlarının ortaya çıkması ve gelirlerin artışında kritik bir rol oynamakla birlikte, beşeri sermayenin ülkelerarası transferine imkan vererek yeni teknolojilerin ve yönetimsel becerilerin bu ülkelere aktarılmasına olanak sağlamaktadır. $\mathrm{Bu}$ nedenle, iktisadi büyüme hedeflerinin gerçekleştirilmesinde önemli dinamiklerden birisi olan doğrudan yabancı sermaye akımları, başta sermaye yetersizliği olan ülkeler olmak üzere, gelişmekte olan ekonomilerin başlıca rekabet alanlarından birisi olmuştur. 1980'li yıllardan itibaren ortaya çıkan finansal liberalizasyon hareketleri ve sermaye piyasalarının entegrasyon süreci, teknolojik gelişmelerin de katkısıyla birlikte yüzyılın sonlarına doğru hızlanmış, özellikle gelişmekte olan ekonomiler, yabancı doğrudan yatırımları çekmek adına köklü politika değişiklerine başvurmuştur. Birleşmiş Milletler Ticaret ve Kalkınma Konferansı (UNCTAD) Dünya Yatırım Raporu (2019)'a göre, 1982'de 57 milyar dolar olan küresel doğrudan yabancı sermaye girişleri, 2018 yılında 1.3 trilyon dolara ulaşmıştır (son küresel ekonomik ve finansal krizler nedeniyle önemli bir daralmayla 2015'teki 1.92 trilyon dolarlık zirveden düşmüştür). Gelişmekte olan ekonomiler, 2018 yılı doğrudan yabancı sermaye girişlerinin yüzde 54'ünü oluştururken, küresel doğrudan yabancı yatırım iç stokları 2017 yılında yaklaşık 31.5 trilyon dolara ulaşmış ve gelişmekte olan ekonomilerin 2000'li yılların başında yaklaşık yüzde 20 olan toplam içerisindeki payı, ucuz işgücü, hammadde ve uygun yatırım ortamları sayesinde yüzde 33 'e yükselmiştir.

Ancak, küreselleşmenin diğer birçok yönünde olduğu gibi, artan doğrudan yabancı sermaye girişlerinin enerji tüketimi üzerindeki etkisi ve çevresel sonuçları da teorik ve ampirik literatürde üzerinde sıkça durulan önemli tartışma alanlarından birisi haline gelmiştir. Paris Anlaşması'nda belirlenen keskin azaltma hedeflerinin aksine, 2018 yılında küresel enerji tüketimi yüzde 2.3 artış göstermiş (2010-2018 dönemi ortalama artış hızının yaklaşık iki katı), enerji tüketimine bağlı karbon emisyonları ise 2018 yılında yüzde 1.7 oranında artış kaydetmiş (2010 - 2018 dönemi ortalama artış hızından daha yüksek ve 2013 yılından bu yana en yüksek büyüme hızı) ve 33.1 gigatona ulaşmıştır (Uluslararası Enerji Ajans1 Küresel Enerji ve CO2 Durumu Raporu, 2019).

$\mathrm{Bu}$ bilgiler 1şı̆̆ında, küresel ekonomideki büyümenin çevresel sonuçlarının özellikle 2000'li yıllardan sonra ulusal ve uluslararası politikaların bir parçası haline gelmesi, teorik ve ampirik literatürde çokça tartışılan bir konu olarak karşımıza çıkması şaşırtıcı değildir. Bu kapsamda, birbiriyle çelişen iki farklı hipotezden bahsedilebilir. Bir görüşe ("kirlilik sığınağı hipotezi”) göre özellikle gelişmekte olan ekonomilerin ekonomik büyümelerini desteklemek adına doğrudan yabancı yatırımları çekme yarışı, çevreci politika uygulamalarının esnetilmesi ve gelişmiş ülkelerde nispi olarak daha sıkı çevre standartlarına tabi olan yatırımların, dolayısıyla da çevresel sorunların, bu bölgelere doğru kaydırılması sonucunu doğurmaktadır. Bu bağlamda, artan üretim oranlarıyla 
birlikte yükselen enerji ihtiyacı ve bunun doğal bir sonucu olarak ortaya çıkan çevresel sorunlar ekolojiyi tehdit ettiği kadar, bu sorunların bertaraf edilmesi adına gelecekte katlanılması gereken potansiyel maliyetleri de beraberinde getirdiği ve ekonomilerin büyüme ve refah düzeyini tehdit ettiği söylenebilir. Diğer bir görüşe ("kirlilik hale hipotezi") göre ise doğrudan yabancı yatırımlar ev sahibi ülkelerde enerji tasarrufunu ve yenilenebilir enerjilerin kullanımını teşvik etmekte, enerji talebini azaltmakta, çevre dostu teknolojiler temin etmekte ve böylece çevresel bozulmaların azalmasını sağlamaktadır. Bu bakımdan doğrudan yabancı yatırımlar, enerji tüketimi, $\mathrm{CO}_{2}$ emisyonu ve iktisadi büyüme arasındaki ilişkilerin doğru tespit edilmesi ve buna ilişkin iktisadi politikaların verimli bir analizi kritik bir önem arz etmektedir. Bahsi geçen değişkenler arasındaki ilişkiler özelinde tüm ülkeler veya belirli bir grup ülke için geçerli bir sonuç ortaya koymak oldukça zor görünmekle birlikte, ülke bazında yapılan analizlerin daha çok ön plana çıktığını söyleyebiliriz. Bu kapsamda Türkiye, doğrudan yabancı sermaye yatırımlarının çevresel sonuçlarının değerlendirilebileceği uygun bir inceleme alanı olarak karşımıza çıkmaktadır. Türkiye'de, özellikle 1980'lerden sonra yabancı sermaye akımlarını düzenleyen kanun ve politikaların revize edilmesi suretiyle önü açılmaya çalışılan doğrudan yabancı sermaye girişleri, 2001 yılına kadar sembolik düzeyde kalmış ve 1 milyar doların altında seyretmiştir. 2001 yılında Uluslararası Para Fonu (IMF) tarafindan da desteklenen Güçlü Ekonomiye Geçiş Programı'nın uygulanmaya başlaması, 2003 yılında çıkarılan 4875 sayılı Doğrudan Yabancı Yatırım Kanunu ile getirilen yenilikler ve 2004 yılında Avrupa Birliği (AB) ile üyelik müzakerelerinin resmen başlaması ile birlikte yukarı yönlü bir ivme yakalayan ve 2000 yılında 982 milyon dolar olan doğrudan yabancı sermaye girişleri, 2007'de 22 milyar doları aşmıştır. 2008-2009 global krizinin etkisiyle sert bir düşüş yaşayan yabancı sermaye girişi, krizin etkilerinin hafiflemesiyle birlikte dalgalı bir seyir izlemesine rağmen, 2015 yılında 17.6 milyar dolara ulaşmıştır. Ancak özellikle Temmuz 2016 darbe girişimi sonrası ortaya çıkan siyasi havanın etkisiyle 2016 yılındaki sert düşüşün ardından, 2017 yılında 11 milyar dolara gerileyen doğrudan yabancı sermaye girişleri, 2018 yılında toparlanarak 13 milyar dolar olarak gerçekleşmiştir. Suudi Arabistan'la birlikte Batı Asya'daki en büyük doğrudan yabancı sermaye alıcılarından birisi olan Türkiye, bu bölgedeki doğrudan yabancı sermaye girişlerinin yüzde 25 'inden fazlasına ev sahipliği yapmaktadır (UNCTAD, 2018 ve 2019). Türkiye'de doğrudan yabancı sermaye girişlerinin ivme kazandığ 1 son 20 yıllık dönem, aynı zamanda enerji tüketimi ve sera gazı emisyon oranlarının hızla arttığı bir dönem olarak karşımıza çıkmaktadır. Türkiye İstatistik Kurumu (TÜİK) verilerine göre, Türkiye'de 1990 y1lında yaklaşık 219 milyon ton karbondioksit eşdeğeri olan toplam sera gazı emisyonu, 2017 yılında yaklaşık 526 milyon tona yükselerek yüzde 140 artış göstermiştir (1990-2000 dönemindeki artış yüzde 36, 2000-2017 arası dönemdeki artış ise yüzde $87^{\prime}$ 'dir). Verilere göre, aynı dönem içerisinde kişi başı karbondioksit eşdeğer emisyonu 4 tondan 6.6 tona yükselmiştir (en büyük payı yüzde 72.2 ile enerji kaynaklı emisyon oluşturmaktadır). Dünya Bankası'nın Dünya Kalkınma Göstergeleri (World Development Indicators - WDI) verilerine 
göre ise, sera gazlarının en büyük bölümünü oluşturan karbondioksit $\left(\mathrm{CO}_{2}\right)$ emisyonları, 1990-2014 döneminde yüzde 137'lik bir artış göstermiş, kişi başı karbon emisyonu 1.66 kat artarak 4.48 metrik tona yükselmiştir. Kişi başı birincil enerji tüketimi ise aynı dönemde 1.69 kat artarak yaklaşık 1574 kilogram petrol eşdeğerine ulaşmıştır.

Özet olarak Türkiye, son dönemde uyguladığı yapısal reformlar ve ekonomik büyüme performansıyla doğrudan yabancı sermaye akımlarının hedef ülkelerinden birisi haline gelmiştir. Nitekim, Ernst ve Young'ın (2019) Avrupa Ülke Çekiciliği Araştırması'na göre, Türk lirasının belirgin bir şekilde değer kaybetmesine ve siyasi belirsizlik baskısına rağmen, sahip olduğu güçlü sanayisi ve ucuz vasıflı işgücüyle, 2019 yılı itibarıyla doğrudan yabancı yatırım açısından Avrupa'nın en popüler yedinci ülkesi konumundadır. Ancak Türkiye, sera gazı emisyonlarında en büyük sorumluluğa sahip ülkeler arasında olmamakla birlikte, emisyonlarını hızla artıran bir ülke konumundadır. Bu kapsamda özellikle son yıllarda, Türkiye'nin bahsi geçen hususlar açısından nerede durduğunu analiz eden çalışmaların sayısı belirgin bir artış göstermiştir. Bir sonraki bölümde detaylandırılacak olan bu çalışmalardan farklı olarak, mevcut analiz, Yönlendirilmiş Döngüsüz Graflar (DAGs) yardımıyla tümevarımlı nedensel çıkarım şablonları oluşturarak, değişkenler arasındaki ilişkiler hakkında önsel varsayımlar yapmadan Türkiye'de doğrudan yabancı sermaye yatırımları, karbon emisyonu, enerji tüketimi ve ekonomik büyüme arasındaki nedensellikleri ve doğrudan yabancı yatırımların çevresel etkilerini ortaya koymaktadır. Böylece, mevcut ampirik literatüre metodolojik bir katkı sağlayarak, çevresel düzenlemeler ve yatırım stratejileri konusunda politika yapıcılara hedef gösterilmesi amaçlanmaktadır.

\section{Literatür Çalışmaları}

Doğrudan yabancı yatırımlar/diş ticaret hacmi, enerji tüketimi, $\mathrm{CO}_{2}$ emisyonu ve gelir/iktisadi büyüme arasındaki ilişkileri inceleyen çalışmalar genel olarak beş ayrı grupta sınıflandırılabilir. İlk gruptaki çalışmalar daha çok çevre bozulmaları ve iktisadi büyüme arasındaki ilişkilerin Çevresel Kuznets Eğrisi (ÇKE) hipotezini destekleyip desteklemediği üzerine yapılan çalışmalardan oluşmaktadır. ÇKE hipotezine göre gelir ve çevresel bozulma arasında ters U şeklinde bir ilişki mevcut olup kişi başına düşen $\mathrm{CO}_{2}$ (veya diğer bir sera gazı) salınımı iktisadi kalkınmanın ilk aşamalarında artmakta; kişi başına düşen gelirin belirli bir seviyeye ulaşmasıyla birlikte ters yönlü bir ilişki ortaya çıkmaktadır. Genel olarak bu kategoride yer alan çalışmaların kullandıkları metodolojiler ve elde ettikleri sonuçlar itibarıyla çeşitlilik gösterdiği söylenilebilir (bkz. Selden ve Song, 1994; Grossman ve Krueger, 1995; Holtz-Eakin ve Selden, 1995; Roberts ve Grimes, 1997; Suri ve Chapman, 1998; Galeotti vd., 2006; Ang, 2007; Cole, 2005; Richmond ve Kaufmann, 2006; Jinke vd., 2008; Managi ve Jena, 2008; Aslanidis ve Iranzo, 2009; Narayan ve Narayan, 2010; Kijima vd., 2010; Iwata, Okada vd., 
2010; Saboori vd., 2012; Zanin ve Marra, 2012; Osabuohien, Efobu vd., 2014; Aye ve Edoja, 2017; Özokçu ve Özdemir, 2017; Acar vd., 2018).

İkinci grup çalışmalar, ağırlıklı olarak enerji tüketimi ve kirlilik arasındaki ilişkiyi inceleyen çalışmalardan oluşmaktadır. Çoğu zaman ekonomik büyüme/gelir değişkeni de analize dahil edilerek çok değişkenli modeller kullanılmıştır. Elde edilen bulgular, çalışmaların hem örneklem hem de zaman periyodu ve kullanılan metodolojiler açısından farklılık arz etmesi sebebiyle çeşitlilik göstermektedir (bkz. Squalli, 2007; Zhang ve Cheng, 2009; Soytaş ve Sarı, 2009; Öztürk ve Acaravc1, 2010; Arouri vd., 2012; Bölük ve Mert, 2014 ve 2015; Akpan ve Akpan, 2012; Bloch vd., 2012; Saboori ve Sulaiman, 2013; Salahuddin ve Gow, 2014; Saidi ve Hammami, 2015; Wang vd., 2016; Magazzino, 2016).

Enerji tüketimi ve iktisadi büyüme arasındaki nedenselliğin varlığını ve yönünü ortaya koyan çalışmalar ise üçüncü grubu oluşturmaktadır. Bu alanda yapılan çalışmaların sayısı oldukça fazla olmakla birlikte, sonuçları itibarıyla farklılık gösterdikleri ve hatta birbirleriyle çeliştikleri ifade edilebilir (bkz. Kraft ve Kraft, 1978; Akarca ve Long, 1979; Yu ve Choi, 1985; Erol ve Yu, 1987; Abosedra ve Baghestani, 1991; Stern, 1993 ve 2000; Masih ve Masih, 1996; Zarnikau, 1997; Yuan vd., 2008; Belloumi, 2009; Hondroyiannisa vd., 2002; Soytaş ve Sarı, 2003 ve 2006; Ghali ve El-Sakka, 2004; Paul ve Bhattacharya, 2004; Lee ve Chang, 2005 ve 2008; Narayan ve Smyth, 2007; Akinlo, 2008; Huang vd., 2008; Apergis ve Payne, 2009; Bartleet ve Gounder, 2010; Tsani, 2010; Belke vd., 2011; Shahbaz vd., 2012; Farhani ve Rejeb, 2012; Herrerias vd., 2013; Arora ve Shi, 2016).

Dördüncü gruptaki çalışmalar ise uluslararası ticaret ve sabit sermaye akımları ile çevre bozulmaları arasındaki ilişkiye odaklanan çalışmalardır. Bu kapsamda ortaya atılan başlıca iki hipotez ise yukarıda bahsi geçen Kirlilik Hale Hipotezi ve Kirlilik Sığınağı Hipotezidir. Ampirik literatürde her iki hipotezi de destekleyen çok sayıda çalışma vardır. Kirlilik sığınağı (cenneti) hipotezini destekleyen çalışmalara Birdsall ve Wheeler (1993), van Beers ve van den Bergh (1997), List ve Co (2000), Grimes ve Kentor (2003), Hoffmann vd. (2005) gibi çalışmalar örnek verilebilir. Porter ve van der Linde (1995), Letchumanan ve Kodama (2000), Eskeland ve Harrison (2003), Akın (2014) gibi çalışmalar ise Kirlilik Hale Hipotezini destekleyen bulgulara ulaşmışlardır. Literatürde uluslararası şirketlerin, katı çevresel düzenlemelerin olduğu gelişmiş ülkelerden ziyade, yatırım tercihlerini, maliyetleri azaltmak adına çevresel düzenlemelerin daha gevşek olduğu gelişmekte olan ülkelerden yana kullandıklarına dair baskın bir görüş olduğunu belirtebiliriz. Genel olarak, uluslararası firmaların doğası ve motivasyonuna bağlı olarak doğrudan yatırımların kirliliği arttırabileceği yorumu yapılabilir.

Beşinci grup ise bahsi geçen bütün değişkenlerin (doğrudan yabancı yatırım/ticaret, ekonomik büyüme/gelir, enerji tüketimi, çevre bozulmaları) arasındaki ilişkilerin çok değişkenli bir model içerisinde analize tabi tutulduğu 
çalışmaları kapsamaktadır (Pao ve Tsai, 2011; Jayanthakumaran vd., 2012; Chandran ve Tang, 2013; Lee, 2013; Kohler, 2013; Bouttabba, 2014; Lau vd., 2014; Khachoo ve Sofi, 2014; Kivyiro ve Arminen, 2014; Linh ve Lin, 2014; Tang ve Tan, 2015; Öztürk ve Öz, 2016).

Halıcıoğlu (2009), 1960-2005 dönemi için Türkiye'de karbon emisyonları, enerji tüketimi, gelir ve dış ticaret arasındaki dinamik nedensel ilişkileri araştırmıştır. Sınır testi sonuçları, uzun dönemde karbon emisyonlarının belirleyicilerinin enerji tüketimi, gelir ve dış ticaret olduğunu, gelirin uzun dönem belirleyicilerinin ise karbon emisyonları, enerji tüketimi ve dış ticaret olduğunu işaret etmektedir. Bunun yanında, ampirik sonuçlar, gelirin karbon emisyonlarını açıklamada en anlamlı değişken olduğunu ortaya koymaktadır.

Pao ve Tsai (2011), panel eş bütünleşme ve Granger nedensellik testlerini kullanarak BRIC (Brezilya, Rusya, Hindistan ve Çin) ülkelerinde doğrudan yabancı yatırım, GSYİH, enerji tüketimi ve $\mathrm{CO}_{2}$ emisyonu arasındaki ilişkileri 1980 - 2007 dönemi için (Rusya için 1992 - 2007) analize tabi tutmuştur. Elde edilen sonuçlar, uzun dönemde, karbon emisyonlarının enerji tüketimine elastik, doğrudan yabancı yatırımlara ise inelastik olduğunu ortaya koymuştur. Ayrıca, ÇKE hipotezini destekler bulgulara ulaşılmakla birlikte; nedensellik testi sonuçları, karbon emisyonları ve doğrudan yabancı yatırım, hasıla ve emisyonlar, hasıla ve enerji tüketimi arasında güçlü bir iki yönlü nedensellik olduğunu ve hasıladan doğrudan yabancı yatırımlara ve enerji tüketiminden emisyonlara doğru ise tek yönlü bir nedensellik olduğunu ortaya koymaktadır. Elde edilen bulgular, aynı zamanda kirlilik sığınağı hipotezi, kirlilik hale hipotezi ve ölçek etkisini desteklemektedir.

Jayanthakumaran vd. (2012), $\mathrm{CO}_{2}$ emisyonu, enerji tüketimi, hasıla ve uluslararası ticaret arasındaki uzun ve kısa dönem ilişkiler açısından sınır testi yaklaşımı ve Otoregresif Dağıtılmış Gecikme Modeli (ARDL) metodolojisini kullanarak Çin ve Hindistan'1 kıyaslamaktadır. Elde edilen sonuçlar Çin'de karbon emisyonlarının yapısal değişmeler, kişi başına gelir ve enerji tüketiminden etkilendiğini ortaya koymaktadır. Hindistan'da ise, kayıt dışı ekonominin Çin'e nazaran çok daha büyük olması hasebiyle, yapısal değişimle karbon emisyonu arasında benzer bir bağlantı bulunamamıştır. Yazarlara göre, Hindistan az miktarda enerji tüketen ve uluslararası pazarlarda rekabet şansı olmayan çok sayıda küçük işletmeye sahiptir. $\mathrm{Bu}$ nedenle, birbiriyle çelişen bu senaryoları anlamak, bu iki ülkeyi etkileyen iklim değişikliği üzerinde uluslararası bir uzlaşıya varılması açısından elzemdir.

Chandran ve Tang (2013) eşbütünleşme ve Granger nedensellik metotlarını kullanarak ASEAN (Güneydoğu Asya Ülkeleri Birliği - Endonezya, Malezya, Tayland, Filipinler, Singapur, Bruney, Vietnam, Laos, Myanmar ve Kamboçya) 5 ülkeleri için ulaşım sektörü enerji tüketimi ve doğrudan yabancı sermaye yatırımlarının $\mathrm{CO}_{2}$ emisyonları üzerindeki etkilerini ve ayrıca ÇKE hipotezinin geçerliliğini araştırmışlardır. Araştırma sonuçları karbon emisyonları ve belirleyici faktörlerinin sadece Endonezya, Malezya ve Tayland'da eşbütünleşik 
olduğunu ortaya koymuştur. Ayrıca çalışmada uzun dönem esneklik tahmini yapılarak hasıla ve ulaşım sektörü enerji tüketiminin karbon emisyonlarını etkilediği ancak doğrudan yabancı yatırımların etkisinin anlamsız olduğu sonucuna ulaşılmıştır. Yazarlar, iktisadi büyüme her ne kadar ASEAN 5 ülkelerinde karbon salınımlarında daha büyük bir role sahip olsa da ÇKE hipotezinin bu ekonomilere (özellikle Endonezya, Malezya ve Tayland için) uyarlanamayacağını belirtmişlerdir. Bunlara ek olarak, uzun dönemde, Endonezya ve Tayland için iktisadi büyüme ve karbon salınımları arasında iki yönlü nedensellik, Malezya için ise GSYİH'den karbon emisyonlarına doğru tek yönlü bir nedensellik olduğu sonucuna ulaşılmış, Tayland ve Malezya için ulaşım sektörü enerji tüketimi, doğrudan yabancı yatırımlar ve karbon salınımları arasında iki yönlü nedensellikler olduğu ortaya konulmuştur. Çalışmaya göre, acil bir politika seçeneği olarak, ulaşım sektörü enerji tüketiminin kontrolü, karbon salınımlarının önemli ölçüde azalmasını sağlayabilir. Ancak bu Malezya ve Endonezya'da iktisadi büyüme sürecini yavaşlatabilir. Bu nedenle çalışmada alternatif olarak politika yapıcıları tarafından enerji verimli ulaşım sistemleri üzerinde durulması gerektiği ve fosil yakıt tüketiminin minimuma indirilmesi önerilmektedir.

Lee (2013), Yirmiler Grubu (G20)'de yer alan 19 ülkede 1971-2009 dönemi için, eşbütünleşme testlerini kullanarak doğrudan yabancı yatırım, temiz enerji kullanımı, karbon emisyonları ve ekonomik büyüme arasındaki uzun dönem ilişkilerini araştırmıştır. Test sonuçları, doğrudan yabancı yatırımların ekonomik büyümede önemli bir rol oynadığı ve ekonomik büyümenin, $\mathrm{CO}_{2}$ salınımlarını arttırıcı etkisini sınırladığını ortaya koymaktadır. Çalışmada, doğrudan yabancı yatırımları ile temiz enerji kullanımı arasında istatistiki olarak anlamlı doğrudan bir ilişki tespit edilememiştir.

Kohler (2013), ARDL metodu yardımıyla Güney Afrika için ticaret serbestisinin enerji tüketimi, emisyonlar ve ekonomik büyüme arasındaki ilişkilerde oynadığı rolü tartışmaktadır. Araştırma sonuçları çevre kalitesi, kişi başına enerji kullanımı ve dış ticaret arasında uzun dönemli bir ilişki olduğunu ortaya koymaktadır. Çalışma, kişi başına enerji kullanımının karbon salınımını arttırdığını, ancak artan ticaret hacminin bu emisyonları azalttığını destekler sonuçlara ulaşmıştır. Ayrıca, Granger nedensellik testi sonuçları kişi başına enerji kullanımı ile karbon emisyonları arasında iki yönlü bir ilişki olduğunu teyit etmektedir. Çalışmaya göre, her ne kadar sonuçlar ticaret ve kişi başına gelir ile ticaret ve kişi başına enerji kullanımı arasında iki yönlü nedensellikleri işaret etse de, Güney Afrika'da ticaret serbestisi ne uzun dönem kirlilik yoğun faaliyetlere ne de yüksek emisyon değerlerine katkıda bulunmamıştır.

Bouttabba (2014) Hindistan'1 konu aldığı çalışmasında karbon emisyonları, finansal gelişim, ekonomik büyüme, enerji tüketimi ve ticaret serbestisi arasındaki nedensellik ilişkilerinin varlığı ve yönü üzerinde durmuştur. Elde edilen bulgular bahsi geçen değişkenler arasında uzun dönemli ve nedensel ilişkiler olduğunu 
göstermektedir. Finansal gelişmenin uzun dönemde karbon salınımları üzerinde pozitif bir etkisi olmakla birlikte, finansal büyümeden enerji kullanımına doğru da tek yönlü bir nedensellik vardır. Yazara göre, elde edilen sonuçlar finansal sistemin cari operasyonlarının çevresel yönünü göz önünde bulundurması gerekliliğini ortaya koymaktadır.

Lau vd. (2014) doğrudan yabancı yatırım ve ticaret serbestisinin rolünü göz önünde bulundurarak 1970 - 2008 döneminde Malezya'da ÇKE hipotezinin doğruluğunu hem uzun dönem hem de kısa dönem için test etmiştir. Eşbütünleşme ve Granger nedensellik metodolojisinin sonuçları, doğrudan yabancı yatırım ve dış ticaret kontrol değişkenleri olarak kullanıldığında, ekonomik büyüme ve $\mathrm{CO}_{2}$ emisyonları arasında uzun ve kısa dönemde ters $U$ şeklinde bir ilişki olduğunu ortaya koymaktadır.

Khachoo ve Sofi (2014), 1992-2010 dönemi için BRICSAM (Brezilya, Rusya, Hindistan, Çin, Güney Afrika ve Meksika) ülkelerinde doğrudan yabancı yatırım, iktisadi büyüme, $\mathrm{CO}_{2}$ emisyonu ve enerji kullanımı arasındaki ilişkileri çok değişkenli bir model içerisinde araştırmışlardır. Eşbütünleşme test sonuçları bahsi geçen değişkenler arasında uzun dönemli bir ilişki olduğunu ortaya koymaktadır. Bununla birlikte, doğrudan yabancı sermaye yatırımlarının ekonomik büyüme ve enerji tüketimi üzerinde pozitif bir etkisi olduğunu, ancak karbon emisyonları üzerinde bir etkisi olmadığı sonucuna ulaşılmıştır.

Kivyiro ve Arminen (2014) $\mathrm{CO}_{2}$ emisyonları, enerji tüketimi, iktisadi büyüme ve doğrudan yabancı yatırımlar arasındaki nedensel ilişkileri altı Sahra Altı Afrika ülkesi (Kongo Cumhuriyeti, Demokratik Kongo Cumhuriyeti, Kenya, Güney Afrika, Zambia ve Zimbabve) için araştırmışlardır. ARDL modeli sonuçları bütün değişkenlerin uzun dönemde birlikte hareket ettiğini ortaya koymuş ve Demokratik Kongo Cumhuriyeti, Kenya ve Zimbabve'de ÇKE hipotezini destekler sonuçlar elde edilmiştir. Ayrıca doğrudan yabancı sermaye yatırımlarının bazı ülkelerde karbon emisyonlarını arttırdığına dair bulgular elde edilmiştir. Granger nedensellik testi sonuçları bütün ülkelerde GSYİH'den doğrudan yabancı yatırımlara doğru tek yönlü bir nedenselliğin varlığına ve ülkeden ülkeye değişmekle birlikte diğer değişkenler arasında da nedensellik olduğuna işaret etmektedir. Bahsi geçen değişkenlerden karbon emisyonlarına doğru olan tek yönlü nedensellikler daha çok ÇKE hipotezinin geçerli olduğu ülkelerde görülmüş̧ür.

Linh ve Lin (2014) 1980-2010 dönemi için Vietnam'da $\mathrm{CO}_{2}$ salınımları, enerji tüketimi, doğrudan yabancı sermaye yatırımları ve ekonomik büyüme arasındaki ilişkiyi ÇKE hipotezi, eşbütünleşme ve Granger nedensellik yaklaşımlarını kullanarak analiz etmişlerdir. Ampirik sonuçlar ÇKE hipotezini desteklememekle birlikte, eşbütünleşme ve Granger nedensellik testi sonuçları bahsi geçen değişkenler arasında dinamik bir ilişki olduğunu ortaya koymaktadır. Çalışmaya göre hasıla ve doğrudan yabancı yatırımlar arasındaki kısa dönemli iki yönlü ilişki dolayısıyla, hasıladaki artışların daha fazla yabancı sermaye çekeceği tahmin 
edilmektedir. Ayrıca yazarlara göre değişkenler arasında tespit edilen uzun dönemli iki yönlü nedensellikler önemli politika çıkarımları sağlamaktadır. Enerji verimliliğinin arttırılması ve enerji israfının önüne geçilebilmesi adına enerji altyapısına yapılan yatırımların arttırılması ve enerji tasarrufuna teşvik eden politikaların uygulanması gerektiği şeklinde ikili bir strateji tavsiye edilmektedir.

Tang ve Tan (2015) Vietnam'da $\mathrm{CO}_{2}$ emisyonları, enerji tüketimi, doğrudan yabancı yatırımlar ve ekonomik büyüme arasındaki ilişkiyi eşbütünleşme ve Granger nedensellik yaklaşımlarını kullanarak 1976 - 2009 dönemi için araştırmışlardır. Ampirik sonuçlar değişkenler arasında uzun dönem dengesinin varlığını ortaya koymaktadır. Bununla birlikte, ÇKE hipotezini destekler sonuçlar elde edilmiştir. Ayrıca, karbon emisyonları ve gelir ile doğrudan yabancı sermaye yatırımları ve karbon emisyonları arasında iki yönlü nedensellikler olduğu sonuçlarına ulaşılmış, enerji tüketiminden kısa ve uzun dönemde karbon emisyonlarına doğru nedensellik olduğu saptanmıştır. Başka bir ifade ile Vietnam'da karbon salınımlarının başlıca belirleyicilerinin enerji tüketimi, doğrudan yabancı yatırımlar ve hasıla olduğu ifade edilmiştir. Bu yüzden, yazarlara göre, yabancı yatırımların çevre dostu teknolojilere adaptasyonu, karbon salınımlarının azaltılmasında ve aynı zamanda sürdürülebilir bir ekonomik büyümenin ortaya çıkmasında büyük önem arz etmektedir.

Şeker vd. (2015), Türkiye'yi ele aldıkları çalışmalarında, 1974-2010 için doğrudan yabancı yatırımlar ve enerji tüketiminin karbon emisyonu üzerindeki etkilerini incelemiş ve ÇKE hipotezinin geçerliliğini incelemiştir. ARDL metodolojisi kullanılarak elde edilen bulgular, uzun ve kısa dönem için benzer sonuçlar ortaya koymakta ve doğrudan yabancı yatırımların karbon emisyonları üzerinde pozitif fakat nispi olarak zayıf bir etkisi olduğunu, enerji tüketimi ve GSYİH'nin ise $\mathrm{CO}_{2}$ emisyonunu önemli derecede tetiklediğini göstermektedir. Granger nedensellik testi sonuçları ise bahsi geçen değişkenlerden karbon emisyonlarına doğru tek yönlü nedenselliği işaret etmektedir.

Öztürk ve Öz (2016) Türkiye için yaptıkları çalışmalarında 1974-2011 döneminde enerji tüketimi, gelir, doğrudan yabancı yatırımlar ve $\mathrm{CO}_{2}$ emisyonu arasındaki ilişkiyi Maki (2012) kointegrasyon yöntemi ve Granger nedensellik testini kullanarak analiz etmişlerdir. Analiz sonuçları, bahsi geçen değişkenler arasında uzun dönemli bir ilişski olduğunu ortaya koymaktadır. Ayrıca ÇKE ve Kirlilik Hale Hipotezini destekler sonuçlara ulaşılmış, enerji tüketiminden ekonomik büyümeye doğru tek yönlü bir nedensellik ilişkisi tespit edilmiştir.

Doğrudan yabancı yatırım girişleri ve karbon emisyonları arasındaki ilişkiyi Türkiye özelinde inceleyen bir diğer çalışma Üzar (2019) ise doğrudan yabancı yatırım girişleri, ekonomik büyüme, gayrisafi sabit sermaye oluşumu, ticari dışa açıklık ve karbon emisyonu arasındaki dinamik ilişkileri 1974-2010 dönemi için incelemiştir. Sınır testi sonuçları bahsi geçen değişkenler arasında uzun dönem ilişkinin varlığına işaret etmekle birlikte, ARDL modeli sonuçları, "dibe doğru 
yarış" ve "kirlilik sığınağı” hipotezlerinin Türkiye için geçerli olmadığını ancak ÇKE hipotezinin geçerliliğini ortaya koymaktadır.

Üzar ve Eyuboğlu (2019) ise Türkiye'de doğrudan yabancı yatırım, iktisadi büyüme, enerji tüketimi ve ticari dışa açıklık arasındaki uzun dönemli ilişkiyi, Fourier ADL ve ARDL eşbütünleşme testleri yardımıyla 1980-2015 dönemi için incelemektedir. Ampirik bulgular serilerin eşbütünleşik olduğunu ortaya koymakla birlikte, iktisadi büyüme ve ticari dışa açıklığın hem kısa hem de uzun dönemde enerji tüketimini artırdığını, doğrudan yabancı yatırımların ise sadece uzun dönem enerji tüketimi artışını tetiklediğini ortaya koymaktadır. Vektör Hata Düzeltme Modeli (VECM) nedensellik test sonuçları ise doğrudan yabancı yatırım, ticari dışa açıklık ve ekonomik büyümeden enerji tüketimine doğru tek yönlü bir nedenselliği işaret etmektedir.

Türkiye'de dış ticaret ve doğrudan yabancı yatırımların karbon emisyonları üzerindeki potansiyel asimetrik etkisi ise Haug ve Ucal (2019) tarafindan incelenmiştir. 1974-2014 dönemi için simetrik ve asimetrik ARDL modelleri kullanılarak yapılan analiz sonuçları ihracat, ithalat ve doğrudan yabancı yatırımların $\mathrm{CO}_{2}$ emisyonları üzerindeki asimetrik etkisini ortaya koymakla birlikte, doğrudan yabancı yatırımların uzun dönemde karbon emisyonları üzerinde istatistiki olarak anlamlı bir etkisi olmadığını göstermektedir. Spesifik olarak, ihracattaki azalışlar uzun dönemde kişi başına karbon emisyonlarını artırırken, ihracat rakamlarındaki artışların anlamlı bir etkisi tespit edilememiştir. Benzer şekilde, ithalat rakamlarındaki artışlar kişi başına $\mathrm{CO}_{2}$ emisyonlarını artırırken, ithalattaki azalmanın uzun dönem etkisi anlamlı değildir. Bunun yanı sıra, bahsi geçen değişkenlerin karbon yoğunluğu üzerinde anlamlı bir etkisi olmadığ1 sonucuna ulaşılmış, ancak finansal gelişim ve şehirleşmenin karbon yoğunluğunun belirleyicileri olduğu tespit edilmiştir. Çalışmada ayrıca, her iki karbon emisyonu göstergesi için ÇKE hipotezinin geçerliliği ortaya konulmuştur.

\section{Veriler ve Ampirik Analiz}

$\mathrm{Bu}$ çalışmada, Türkiye' de $\mathrm{CO}_{2}$ emisyonları, enerji tüketimi, doğrudan yabancı yatırım akımları, dış ticaret ve iktisadi büyüme arasındaki eşzamanlı ilişkiler tespit edilmeye çalışılmıştır. Bu amaçla, bahsi geçen değişkenlere ait 1974 - 2014 dönemini kapsayan veriler analiz edilerek Yönlendirilmiş Döngüsüz Graflar metodu kullanılmış ve tümevarımlı nedensel çıkarım şablonları oluşturulmuştur. Çalışmaya ait zaman aralığı, karbon emisyonu ve enerji tüketimi verilerinin elde edilebilirliği göz önünde bulundurularak belirlenmiştir. Çalışmada kullanılan değişkenler, ilgili literatürde sıkça kullanılan değişkenlerden yola çıkılarak seçilmiş ve bu kapsamda karbon emisyonunu temsilen kişi başına $\mathrm{CO}_{2}$ salınımı (metrik ton) (ln_co2_cap), iktisadi büyümeyi temsilen kişi başına Reel Gayri Safi Yurtiçi Hasıla (2010 fiyatlarıyla, US\$) (ln_r_gdppc), enerji tüketimini temsilen kişi başına enerji tüketimi (kg petrol eşdeğeri) (ln_energy_cap), doğrudan yabancı sermaye akımlarını temsilen net doğrudan yabancı sermaye yatırımlarının GSYİH içerisindeki payı (ln_fdi_gdp) ve dış ticaret hacmini (ticari dışa açıklık) temsilen 
ise ihracat ve ithalat toplamının GSYİH içerisindeki payına (ln_trade_gdp) ilişkin veriler kullanılmıştır. Serilere ait yıllık veriler, Dünya Bankasının "World Development Indicators" (WDI) veri tabanından elde edilmiş, bütün seriler logaritmik formda analize dahil edilmiştir.

İktisat literatüründe, ekonomik modellerin parametrelerini ve yapısını ölçmek ve tanımlamak adına çoğunlukla iktisat teorisi ve araştırmacıların önsezilere dayanan çalışmalar ortaya konulmuştur. Ancak teorinin çoğu zaman, çalışma konusu yapılan değişkenler arasındaki nedensel yapıyı tanımlamak için yeterli bilgiyi sağlayamamakla birlikte, oldukça heterojen olduğu da ifade edilebilir. Ayrıca, teorik olarak nedensel yapı verilerin istatistiksel özellikleri tarafından belirlendiği için gözlemsel verilere dayanan nedensel yapı, teoriye dayanan modeller tarafından belirlenememekte ve yanlış nedensel çıkarımlar yapılabilmektedir. (Kwon ve Bessler, 2011). Dolayısıyla, doğuştan idelerden (düşünce) ya da varsayılan davranışların matematiğinden ortaya çıkan "tümdengelimsel nedensellik"ten ziyade, gözlemsel verilere dayanan ve değişkenler arasındaki koşullu bağımsızlıklardan nedensel graflar oluşturmaya yardımcı olan "tümevarımsal nedensellik", değişkenler arasındaki ilişkilerin tespitinde sağlıklı sonuçlara ulaşılmasına katkıda bulunabilir (Liv vd., 2013; Benli, 2019).

Nedensel modellemede yaygın bir şekilde kullanılan Yönlendirilmiş Döngüsüz Graflar (DAGs), basit bir ifadeyle yönlendirilmiş döngüler içermeyen yönlendirilmiş graflar (digraf) olarak tanımlanabilir. Digraf, boş olmayan sonlu bir düğümler (köşe, değişken) kümesi (V) ve yönlendirilmiş ayrıtlar (ok, bağlantı) kümesinden $(\mathrm{E})$ oluşan matematiksel bir nesnedir $(\mathrm{G}=(\mathrm{V}, \mathrm{E}))$. Dügüumler değişkenleri, düğümler arası yönlendirilmiş ayrıtlar ise ilgili değişkenler arasındaki ilişkiyi temsil etmektedir. Örneğin, $\mathrm{V}=\{\mathrm{A}, \mathrm{B}, \mathrm{C}\}$ ve $\mathrm{E}=\{(\mathrm{B}, \mathrm{A}),(\mathrm{C}$, A)\} olsun. $\mathrm{Bu}$ durumda $\mathrm{G}=(\mathrm{V}, \mathrm{E})$, Şekil 1(a)'da temsili olarak gösterilen yönlendirilmiş bir graftır. Dikkat edilirse, yönlendirilmiş graf $\mathrm{G}$ herhangi bir yönlendirilmiş döngü içermemektedir (herhangi bir düğümden başlayarak yönlendirilmiş okları takip ederek aynı düğüme dönmek mümkün değildir). Bu sebeple Şekil 1(a)'da temsil edilen $G=(V, E)$, yönlendirilmiş döngüsel olmayan bir graf olarak ifade edilir. Buna karşın, Şekil 1(b)'de temsil edilen G' $=(V, E$ ') döngüseldir $\left(\mathrm{E}^{\prime}=\{(\mathrm{B}, \mathrm{A}),(\mathrm{A}, \mathrm{C}),(\mathrm{C}, \mathrm{B})\}\right)$. Çünkü bu durumda, $\mathrm{B}$ düğümünden $\mathrm{A}$ düğümüne doğru başlayan bir hareket $C$ düğümü üzerinden $B$ düğümünde sonlanır. Bu çalışmada, döngüsel graflar tanımlanamadığı için, Şekil 1(a) ve Şekil 2'deki gibi döngüsel olmayan graflar üzerinde durulacaktır.

Nedensel modelde birbirlerine bir ayrıtla bağlanan düğümler komşu düğümler olarak tanımlanmaktadır. Modelde yer alan değişkenlere atıfta bulunurken ise şecere terimleri kullanılır. Kendisine herhangi bir ayrıt yönlendirilen düğüm çocuk düğümü (child node) olarak adlandırılırken, ayrıtların çıktığı düşüm ebeveyn dügüm (parent node) olarak ifade edilir. Ebeveyn dügümler aynı zamanda ata düğümler (ancestors), çocuk düğümler ise torun veya soy (descendant) düğüm olarak isimlendirilir. Örneğin, Şekil 2'de temsil edilen 
yönlendirilmiş döngüsüz grafta, $\mathrm{x}$ ve y değişkenleri $\mathrm{z}$ değişkeninin ata düğümleri iken, $\mathrm{z}$ değişkeni $\mathrm{x}$ ve y değişkenlerinin soy düğümüdür. Ayrıca, x değişkeni, $\mathrm{z}$ değişkeninin ata dügümü, y değişkeninin ise ebeveyn dügümüdür. Benzer şekilde, $\mathrm{z}$ değişkeni, $\mathrm{x}$ değişkeninin torunu, $\mathrm{y}$ değişkeninin ise çocuk düğümüdür.

Şekil 1: Digraf Örnekleri

(a)

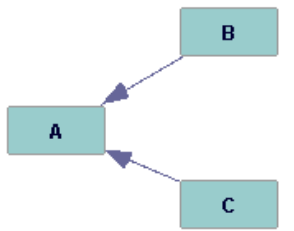

(b)

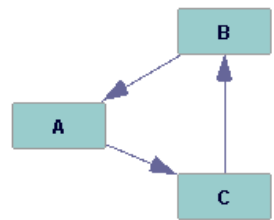

Şekil 2: DAG Örneği

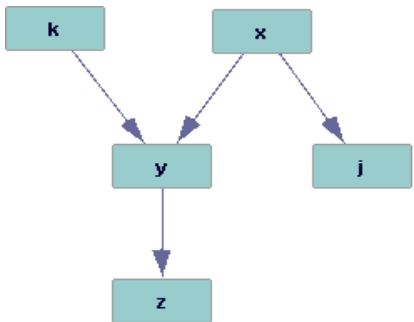

Matematiksel olarak DAGs, lineer tekrarlı çarpım ayrışımları tarafindan ifade edilen koşullu bağımsızlıkların temsilleri olarak ifade edilebilir (zincir kuralı) (Pearl, 1995):

$\operatorname{Pr}\left(v_{1}, v_{2}, v_{3}, \ldots, v_{n}\right)=\prod_{\mathrm{i}=1}^{\mathrm{n}} \operatorname{Pr}\left(v_{i} \mid \mathrm{pa}_{\mathrm{i}}\right)$

Burada $\operatorname{Pr}$, düğümlerin $\left(\mathrm{v}_{1}, \mathrm{v}_{2}, \mathrm{v}_{3}, \ldots ., \mathrm{v}_{\mathrm{n}}\right)$ olasılığını, $\mathrm{pa}_{\mathrm{i}}$ ise sirasıyla $\mathrm{v}_{\mathrm{i}}{ }^{\prime}$ den nedensellik anlamında önce gelen değişkenlerin (ebeveyn düğümler) bazı alt kümelerinin gerçekleşmesi durumunu temsil etmektedir. Başka bir deyişle, dügümlerin olasılı̆̆ 1 , tüm dügüumlere ait koşullu olasılık değerlerinin çarpılmasıyla elde edilmektedir. Örneğin, Şekil 3'teki DAG, aşağıda verilen Eşitlik 2'de yer alan ayrışımın temsilidir.

$\operatorname{Pr}\left(v_{1}, v_{2}, v_{3}, v_{4}, v_{5}\right)=\operatorname{Pr}\left(v_{1}\right) \operatorname{Pr}\left(v_{2} \mid v_{1}\right) \operatorname{Pr}\left(v_{3} \mid v_{1}\right) \operatorname{Pr}\left(v_{4} \mid v_{2}, v_{3}\right) \operatorname{Pr}\left(v_{5} \mid v_{4}\right)$

Eşitlik 1'de yer alan lineer tekrarlı çarpım ayrışımları, ebeveyn kümesi veri iken, her değişkenin $\left(v_{i}\right)$ diğer bütün ata düğümlerinden $\left\{v_{1}, v_{2}, \ldots, v_{i-1}\right\}$ koşullu bağımsızlıklarını temsil etmektedir (Markov özelliği). Verma ve Pearl (1988), aynı çalışmada tanımlanan yönlü ayırma (d-separation) prosedürü kullanılarak koşullu bağımsızlıkların grafikleştirilebileceğini göstermiş, yönlü ayırma prosedürünün gözlemsel verilere uygulanarak yönlü grafların oluşturulmasına imkan veren PC (kısmi korelasyon) algoritması ise Spirtes vd. (2000) tarafindan geliştirilmiştir. 
Şekil 3: Eşitlik 2'deki Ayrışımı Temsil Eden DAG

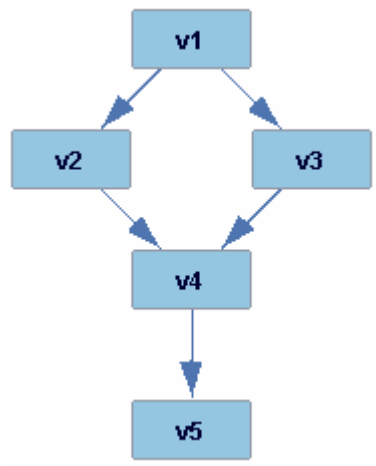

PC algoritması, değişkenler arasındaki nedensel yapıyı üç adımda belirler. Algoritma, sistem içerisindeki her değişkenin yönlendirilmemiş bir ayrıtla diğer değişkenlere bağlandığı (örneğin, A - B) bir tam yönlendirilmemiş grafin oluşturulmasıyla başlar (Şekil 4). Daha sonra algoritma, değişken çiftleri arasındaki koşulsuz korelasyonları göz önünde bulundurarak ayrıtları yönlendirilmemiş graftan çıkarır. Başka bir ifadeyle, sıfır korelasyona sahip değişkenleri birbirine bağlayan ayrıtlar kaldırılır. Geriye kalan ayrıtlar için ise, birinci derece kısmi korelasyonun (iki değişken arasındaki üçüncü bir değişkene bağlı-koşullu olan korelasyon) sıfira eşit olup olmadığı kontrol edilir (uygulamada koşullu korelasyonların sıfırdan farklı olup olmadığının tespiti için Fisher'ın z istatistiği kullanılmaktadır).

Şekil 4: İlgili Değişkenlere ait Yönlendirilmemiş Graf Bütünü

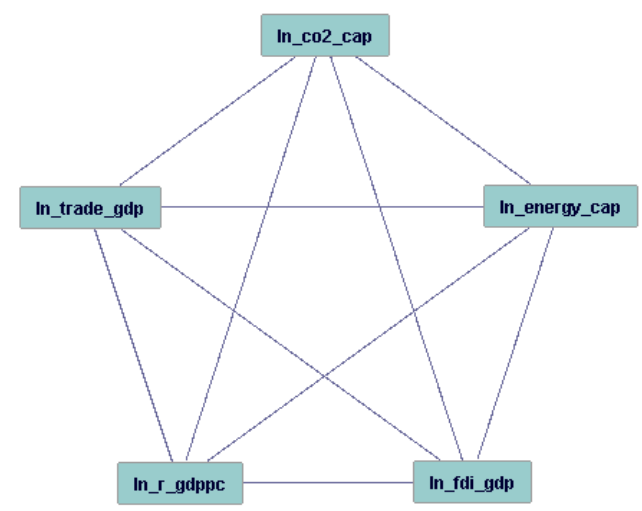

Eğer birinci derece kısmi korelasyon sıfır ise bu değişkenleri birbirine bağlayan ayrıtlar kaldırılır. Bütün bu aşamaları geçen ayrıtlar daha sonra, sıfır ikinci derece koşullu korelasyona testine tabi tutulur ve süreç bu şekilde devam eder (algoritma $\mathrm{N}$ sayıdaki değişken için, (N-2)'nci derece koşullu korelasyona kadar bu işlemi sürdürür) (Yang vd., 2006). Algoritmanın işleyişi ve DAG şablonlarının 
oluşturulmasıyla ilgili bilgilere Spirtes vd. (2000)'de detaylı şekilde yer verilmiştir. PC algoritması ve uzantıları, bu çalışmanın amacı doğrultusunda kullanılan TETRAD VI yazılım programında mevcuttur.

PC algoritması, Monte Carlo simülasyonlarına göre, özellikle 100 gözlemden daha az örneklem büyüklüklerinde, ayritların yönlerini tayin etmede ve ayrıt çıkarma/ekleme aşamasında hatalar yapabilmektedir (Spirtes vd. 2000; Demiralp ve Hoover, 2003; Zhang vd., 2006). Bundan dolay1, Spirtes vd. (2000) örneklem büyüklüğü azaldıkça daha yüksek anlamlılık düzeyleri, örneklem büyüklüğü arttıkça daha düşük anlamlılık düzeyleri kullanılmasını tavsiye etmektedir. Çalışmamızın kapsadığı dönem (1974-2014, 41 adet gözlem) göz önünde bulundurularak analizde, açık şekilde belirli bir yönlendirilmiş sıralamayı veren \%30 anlamlılık düzeyi kullanılmıştır.

Şekil 5: Yönlendirilmiş Graf (PC Algoritması)

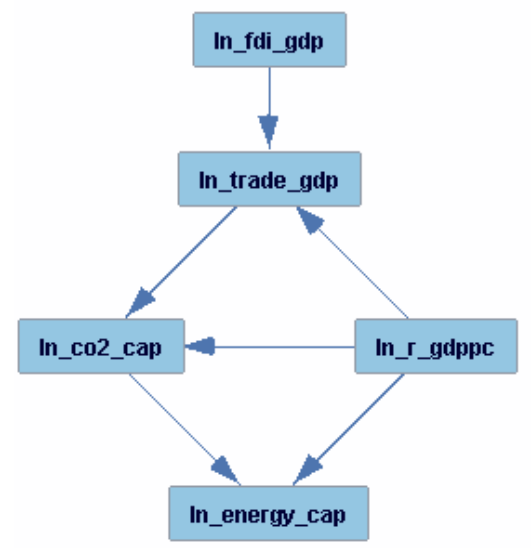

PC algoritması yardımıyla oluşturulan graf, Şekil 5'te verilmiştir. Elde edilen tümevarımlı nedensel çıkarım şablonu, kişi başı gelir ve diş ticaret hacminin, kişi başı $\mathrm{CO}_{2}$ emisyonunu doğrudan etkilediğini, doğrudan yabancı yatırımların ise karbon emisyonlarını dış ticaret hacmi üzerinden dolaylı olarak etkilediğini göstermektedir. Kişi başına GSYİH, dış ticaret hacmi üzerindeki etkisi yoluyla da karbon emisyonlarını dolaylı olarak etkilemektedir. Ampirik sonuçlar, diğer taraftan, kişi başı karbon emisyonları ve kişi başına gelirden kişi başı enerji tüketimine doğru tek yönlü bir nedenselliği işaret etmektedir.

Analiz sonuçları ayrıca, doğrudan yabancı sermaye yatırımları ve kişi başına gelirden ticaret hacmine doğru tek yönlü nedensellikler işaret etmekte, bu bulgular ise, literatürde genellikle, Türkiye özelinde, nedenselliğin dış ticaret hacminden ekonomik büyümeye doğrudan yabancı yatırımlara doğru olduğunu (Özel ve Sezgin, 2014, Karış ve Ayla, 2018) ya da bu değişkenler arasında anlamlı bir nedensellik olmadığını öne süren çalışmaların (Topallı, 2016) ortaya koyduğu sonuçlarla örtüşmemektedir. 
TETRAD IV yazılım programı ayrıca, parametre (düğüm) değerlerine ait maksimum olabilirlik tahminlerinin (maximum likelihood estimates) elde edilmesine de imkan vermektedir. Bu çerçevede, ayrıt katsayılarını (ayrıtlar üzerinde gösterilmiş) ve değişkenlere ait ortalama değerleri (yeşil renkte yazı tipi ile gösterilmiş) gösteren yönlendirilmiş döngüsüz graflar ise Şekil 6' da gösterilmiştir. Elde edilen sonuçlar, sistem içerisinde yer alan bütün değişkenlerin pozitif katsayılı ayrıtlara sahip olduğunu göstermektedir. Spesifik olarak, doğrudan yabancı yatırımlar ve iktisadi büyüme dış ticaret hacmini pozitif olarak etkilerken, dış ticaret ise karbon emisyonlarını artırmaktadır. Ayrıca, ekonomik büyümenin enerji tüketimi ve $\mathrm{CO}_{2}$ emisyonunu artırıcı etkisi tespit edilmiştir. Karbon emisyonlarının enerji tüketimini üzerindeki pozitif etkisi ise, artan karbon emisyonlarının yenilenebilir enerji kaynaklarının kullanımını teşvik ederek yenilenebilir enerji kaynaklarının enerji tüketimi içerisindeki payını artırdığı şeklinde yorumlanabilir.

Şekil 6: Yönlendirilmiş Graf ve Ayrıtlara İlişkin Katsayılar (PC Algoritması)

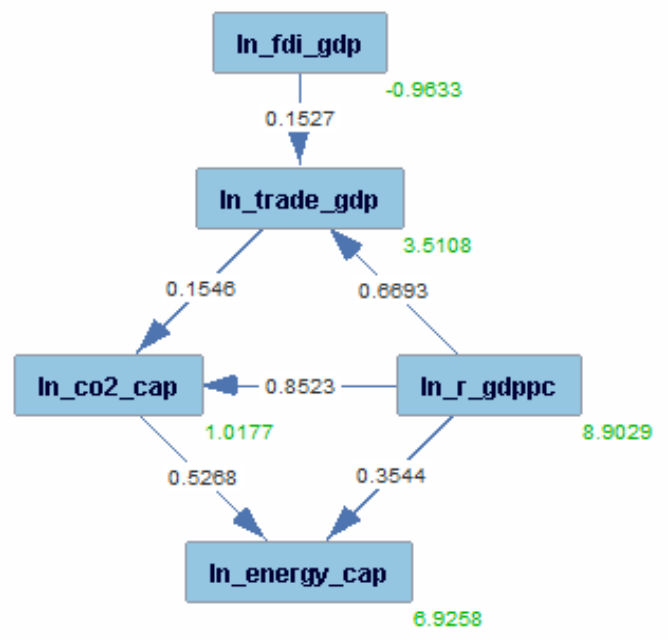

Yukarıda özetlenen analiz sonuçları 1şığında, bu çalışmada elde edilen ampirik bulgular, Halıcıoğlu (2019)'un uzun dönem için elde ettiği gelir ve diş ticaretten karbon emisyonlarına doğru ve Üzar ve Eyuboğlu (2019) tarafindan ortaya konulan ekonomik büyümeden enerji tüketimine doğru tek yönlü nedensellik sonuçlarını teyit etmekte, Öztürk ve Öz (2016) tarafından tespit edilen enerji tüketiminden ekonomik büyümeye doğru ve Şeker vd. (2015) tarafindan tespit edilen enerji tüketiminden karbon emisyonlarına doğru olan tek yönlü nedensellik sonuçlarıyla ise örtüşmemektedir. Çalışma ayrıca, doğrudan yabancı yatırımların dolaylı olarak, dış ticaret hacminin ise doğrudan karbon emisyonlarını tetiklediğini ortaya koymuş ve Üzar (2019)'ın aksine, kirlilik sığınağı hipotezini destekler sonuçlara ulaşmıştır. 


\section{Sonuç}

$\mathrm{Bu}$ çalışmada, doğrudan yabancı yatırımlar, iktisadi büyüme, enerji tüketimi, karbon emisyonları ve ticaret hacmi arasındaki dolaylı ve dolaysız nedenselliklerin yönü ve büyüklükleri, DAGs analizi ile tümevarımlı nedensel çıkarım şablonları oluşturularak tespit edilmeye çalışılmıştır. Elde edilen yönlendirilmiş döngüsüz graf şablonları, iktisadi büyüme ve ticaret hacminin karbon emisyonlarını doğrudan ve pozitif yönde etkilediğini, doğrudan yabancı yatırımların ise dış ticaret hacmi üzerindeki pozitif etkisi ile karbon emisyonlarını dolaylı ve pozitif yönde etkilediğini ortaya koymaktadır. Sonuçlar ayrıca, iktisadi büyümenin enerji tüketimi üzerindeki doğrudan ve artırıcı etkisini işaret etmekle birlikte, karbon emisyonlarının da enerji tüketimi üzerinde doğrudan ve pozitif bir etkisi olduğunu göstermektedir. Bu bulgular, Türkiye'de yeni çevre politikalarının tasarlanması gerekliliğini ortaya koymaktadır. Burada doğrudan yabancı yatırımların ve dış ticaretin sektörel dağılımının ve sektörel emisyonların ayrıntılı bir analizi büyük önem arz etmektedir. Dış ticaretin ve doğrudan yabancı yatırımların diş ticaret hacmi üzerinden karbon emisyonlarını doğrudan tetiklemesi, ithal edilen ve doğrudan yabancı yatırım şeklinde ülkeye girişi gerçekleşen çevresel kirleticilerin tam ölçeğinin belirlenmesi ve buna yönelik politika önlemlerinin alınması zorunluluğunu ortaya koymaktadır. Ekonomik büyüme hızı, doğrudan yabancı yatırım ve dış ticaret hacmindeki azalmaların işsizlik üzerindeki olumsuz etkileri göz önünde bulundurulursa, özellikle kirlilik yoğun sermaye ve mal akımlarının toplam akımlar içerisindeki payını azaltacak politikaların geliştirilmesi gerekmektedir. Elde edilen sonuçlar, ayrıca, iktisadi büyüme hızı düşürülmeden enerji yoğunluğunun ve dolayısıyla emisyonların azaltılabileceğini işaret etmektedir. Yenilenebilir enerji kullanımının teşvik edilerek yaygınlaştırılması enerji yoğunluğunu azaltabileceği gibi, iktisadi büyümenin doğrudan tetiklediği karbon emisyonlarının azaltılması da mümkün olabilir.

Türkiye'nin sera gazı emisyonlarında küresel ölçekte sorumluluğu az olmakla birlikte, Hindistan ve Çin gibi diğer hızlı gelişen ekonomilerle birlikte son yıllarda emisyonlarını artıran bir ülke olarak karşımıza çıkmaktadır. Doğrudan yabancı yatırımlar ve diş ticaret hacmindeki artışlar gelişen ülkelerin küresel ekonomiye entegrasyonunda önemli bir yer tutmakla birlikte, yatırım ve üretim artış1 ile birlikte ortaya çıkan yerel ve global çevresel sorunlar tüm dünya ülkelerini ortak bir çevresel tehditle karşı karşıya bırakmaktadır. Bu itibarla, global ekonominin güçlü aktörleriyle birlikte Türkiye gibi hızla büyüyen ülkelerin de iklim değişikliğiyle mücadeleye yönelik olarak çalışmalar yapması ve uluslararası karar mekanizmaları içerisinde aktif bir rol almaya başlaması elzemdir. Bununla birlikte, literatürde üzerinde çokça durulan ve gelişmiş ülkelerin çok uluslu şirketler aracılığıyla gelişmekte olan ve az gelişmiş ülkelere gerçekleştirdikleri kirlilik transferi tartışmaları, aslında bugün itibarıyla ülkelerin ortak bir paydada buluşmaktan ziyade, belirli coğrafyaları dışlayıcı anlayışın en somut örneği olarak karşımıza çıkmaktadır. Küresel ölçekte hem çevresel sürdürülebilirliğin hem de 
istikrarlı büyümenin başarılabilmesinin bugün ve gelecekteki çözümü, çevre dostu büyümeyi destekleyecek ve emisyon azaltıcı teknolojilerin geliştirilmesine ve ülkeler arası transferine olanak sağlayan ortak küresel ve yerel politikaların geliştirilmesinde yatmaktadır.

\section{Kaynakça}

Abosedra, S. ve Baghestani, H. (1991). New Evidence on The Causal Relationship between United States Energy Consumption and Gross National Product. Journal of Energy and Development, 14, 285-292.

Acar, Y., Gürdal, T. ve Ekeryilmaz, Ş. (2018). Environmental Kuznets Curve for CO2 Emissions: An Analysis for Developing, Middle East, OECD and OPEC Countries. Environmental \& Socio-economic Studies, 6(4), 48-58.

Akarca, A. T. ve Long, T. V. (1980). On The Relationship Between Energy and GNP: A Reexamination. Journal of Energy Development, 5, 326-331.

Akın, C. S. (2014). The Impact of Foreign Trade, Energy Consumption and Income on $\mathrm{CO} 2$ Emissions. International Journal of Energy Economics and Policy, 4(3), 465-475.

Akinlo, A. E. (2008). Energy Consumption and Economic Growth: Evidence from 11 Sub-Sahara African Countries. Energy Economics, 30, 2391-2400.

Akpan, G. E. ve Akpan, U. F. (2012). Electricity Consumption, Carbon Emissions and Economic Growth in Nigeria. International Journal of Energy Economics and Policy, 2(4), 293-308.

Ang, J. (2007). CO2 Emissions, Energy Consumption, and Output in France. Energy Policy, 35, 4772 - 4778.

Apergis, N. ve Payne, J. E. (2009). Energy Consumption and Economic Growth in Central America: Evidence from a Panel Co-integration and Error Correction Model. Energy Economics, 31, 211-216.

Arora, V. ve Shi, S. (2016). Energy Consumption and Economic Growth in the United States. Applied Economics, 48(39), 3763-3773.

Arouri, M. E., Youssef, A., M'henni, H. ve Rault, C. (2012). Energy Consumption, Economic Growth and $\mathrm{CO} 2$ Emissions in Middle East and North African Countries. Energy Policy, 45, 342-349.

Aslanidis, N. ve Iranzo, S. (2009). Environment and Development: Is There a Kuznets Curve for CO2 Emissions? Applied Economics, 41(6), 803-810.

Aye, G. C. ve Edoja, P. E. (2017). Effect of Economic Growth on CO2 Emission in Developing Countries: Evidence from a Dynamic Panel Threshold Model. Cogent Economics and Finance, 5(1), 1-22. 
Bartleet, M. ve Gounder, R. (2010). Energy Consumption and Economic Growth in New Zealand: Results of Trivariate and Multivariate Models. Energy Policy, 38(7), 3508-3517.

Belke, A., Dobnik, F. ve Dreger, C. (2011). Energy Consumption and Economic Growth: New Insights into the Co-integration Relationship. Energy Economics, 33(5), 782-789.

Belloumi, M. (2009). Energy Consumption and GDP in Tunisia: Cointegration and Causality Analysis. Energy Policy, 37(7), 2745-2753.

Benli, M. (2019). Yabancı Portföy Yatırımı - İktisadi Büyüme İlişkisi: Yönlendirilmiş Döngüsüz Graflar Analizi. Erciyes Üniversitesi IIIBF. Dergisi, Say1:53, 59-72.

Birdsall, N. ve Wheeler, D. (1993). Trade Policy and Industrial Pollution in Latin America: Where are the Pollution Havens? Journal of Environment and Development, 2, 137-149.

Bloch, H., Rafiq, S. ve Salim, R. A. (2012). Coal Consumption, CO2 Emission and Economic Growth in China: Empirical Evidence and Policy Responses. Energy Economics, 34, 518-528.

Bölük, G. ve Mert, M. (2014). Fossil \& Renewable Energy Consumption, GHGS (Greenhouse Gases) and Economic Growth: Evidence from a Panel of EU (European Union) Countries. Energy, 74, 439-446.

Bölük, G. ve Mert, M. (2015). The Renewable Energy, Growth and Environmental Kuznets Curve in Turkey: An ARDL Approach. Renewable and Sustainable Energy Reviews, 52, 587-595.

Bouttabba, M. A. (2014). The Impact of Financial Development, Income, Energy and Trade on Carbon Emissions: Evidence from the Indian Economy. Economic Modelling, 40, 33-41.

Chandran, V. G. R. ve Tang, C. F. (2013). The Impacts of Transport Energy Consumption, Foreign Direct Investment and Income on $\mathrm{CO} 2$ Emissions in ASEAN-5 Economies. Renewable and Sustainable Energy Reviews, 24, 445453.

Cole, M. A. (2005). Re-Examining the Pollution-Income Relationship: A Random Coefficients Approach. Economics Bulletin, 14, 1-7.

Demiralp, S. ve Hoover, K. D. (2003). Searching for the Causal Structure of a Vector Autoregression. Oxford Bulletin of Economics and Statistics, 65(1), 745-767.

Ernst \& Young (2019). Europe Attractiveness Survey. http://www.ey.com/Publication/vwLUAssets/ey-europe-attractiveness-survey2019/\$File/ey-europe-attractiveness-survey-2019.pdf (Erişim: 10.01.2020) 
Erol, U. ve Yu, E. S. H. (1987). On the Causal Relationship between Energy and Income for Industrialized Countries. Journal of Energy and Development, 13, 113-122.

Eskeland, G. S. ve Harrison, A. E. (2003). Moving to Greener Pasture? Multinationals and The Pollution Haven Hypothesis. Journal of Development Economics, 70(1), 1-23.

Farhani, S. ve Rejeb, J. B. (2012). Energy Consumption, Economic Growth and CO2 Emissions: Evidence from Panel Data for MENA Region. International Journal of Energy Economics and Policy, 2(2), 71-81.

Galeotti, M., Lanza, A. ve Pauli, F. (2006). Reassessing the Environmental Kuznets Curve for CO2 Emissions: A Robustness Exercise. Ecological Economics, 57, 152-163.

Ghali, K. H. ve El-Sakka, M. I. T. (2004). Energy and Output Growth in Canada: A Multivariate Co-integration Analysis. Energy Economics, 26, 225-238.

Grimes, P. ve Kentor, J. (2003). Exporting the Greenhouse: Foreign Capital Penetration and CO2 Emissions 1980-1996. Journal of World-Systems Research, 9, 261-276.

Grossman, G. M. ve Krueger, A. B. (1995). Economic Growth and the Environment. The Quarterly Journal of Economics, 110(2), 353-77.

Halıcıoğlu, F. (2009). An Econometric Study of CO2 Emissions, Energy Consumption, Income and Foreign Trade in Turkey. Energy Policy, 37, 11561164.

Haug, A. A., ve Ucal, M. (2019). The Role of Trade and FDI for CO2 Emissions in Turkey: Nonlinear Relationships. Energy Economics, 81, 297-307.

Haughton, D., Kamis, A. ve Scholten, P. (2006). A Review of Three Directed Acyclic Graphs Software Packages: MIM, Tetrad, and WinMine, The American Statistician, 60(3), 272-286.

Herrerias, M. J., Joyeux, R. ve Girardin, E. (2013). Short-and Long-Run Causality between Energy Consumption and Economic Growth: Evidence Across Regions in China. Applied Energy, 112, 1483-1492.

Hoffman, R., Lee, C. G., Ramasamy, B. ve Yeung, M. (2005). FDI and Pollution: A Granger Causality Test Using Panel Data. Journal of International Development, 17(3), 311-317.

Holtz-Eakin, D. ve Selden T. (1995). Stoking the Fires? CO2 Emissions and Economic Growth? Journal of Public Economics, 57, 85-101.

Hondroyiannis, G., Lolos, S. ve Papapetrou, E. (2002). Energy Consumption and Economic Growth: Assessing the Evidence from Greece. Energy Economics, 24, 319-336. 
Huang, B. N., Hwang, M. J. ve Yang, C. W. (2008). Causal Relationship between Energy Consumption and GDP Growth Revisited: A Dynamic Panel Data Approach. Ecological Economics, 67, 41-54.

IEA (2019). Global Energy and CO2 Status Report http://www.iea.org/reports/global-energy-and-co2-status-report-2019 (Erişim: 11.01.2020).

Iwata, H., Okada, K. ve Samreth, S. (2010). Empirical Study on the Environmental Kuznets Curve for $\mathrm{CO} 2$ in France: The Role of Nuclear Energy. Energy Policy, 38(8), 4057-4063.

Jayanthakumaran, K., Verma R. ve Liu, Y. (2012). CO2 Emissions, Energy Consumption, Trade and Income: A Comparative Analysis of China and India. Energy Policy, 42, 450-460.

Jinke, L., Hualing, S. ve Dianming G. (2008). Causality Relationship between Coal Consumption and GDP: Difference of Major OECD and non-OECD Countries. Applied Energy, 85, 421-429.

Karış, Ç. ve Ayla, D. (2018). Türkiye'de Doğrudan Yabancı Yatırımlar ve Ticari Dışa Açıklık İlişkisinin Ekonometrik Analizi. Bingöl Üniversitesi Sosyal Bilimler Enstitüsü Dergisi, 8(16), 255-272.

Khachoo, Q. ve Sofi, I. (2014). The Emissions, Growth, Energy Use and FDI Nexus: Evidence from BRICSAM. International Journal of IT, Engineering and Applied Sciences Research, 3(8), 1-9.

Kijima, M., Nishibe K. ve Ohyama A. (2010). Economic Modeling for the Enviromental Kuznets Curve: A Survey. Journal of Economic Dynamics \& Control, 34, 1187-1201.

Kivyiro, P. ve Arminen, H. (2014). Carbon Dioxide Emissions, Energy Consumption, Economic Growth, and Foreign Direct Investment: Causality Analysis for Sub-Saharan Africa. Energy, 74, 595-606.

Kohler, M. (2013). CO2 Emissions, Energy Consumption, Income and Foreign Trade: A South African Perspective. Economic Research Southern Africa, ERSA Working Paper 356.

Kraft, J. ve Kraft, A. (1978). On the Relationship between Energy and GNP. Journal of Energy and Development, 3, 401-403.

Kuznets S. (1955). Economic Growth and Income Inequality. American Economic Review, 45, 1-28.

Lau, L., Choong C. ve Eng, K. (2014). Investigation of The Environmental Kuznets Curve for Carbon Emissions in Malaysia: Do Foreign Direct Investment and Trade Matter? Energy Policy, 68, 490-497. 
Lee, C. C. ve Chang, C. P. (2005). Structural Breaks, Energy Consumption, and Economic Growth Revisited: Evidence from Taiwan. Energy Economics, 27, 857-872.

Lee, C.C. ve Chang, C. P. (2008). Energy Consumption and Economic Growth in Asian Economies: A More Comprehensive Analysis Using Panel Data. Resource and Energy Economics, 30, 50-65.

Lee, J. W. (2013). The Contribution of Foreign Direct Investment to Clean Energy Use, Carbon Emissions and Economic Growth. Energy Policy, 55, 483-489.

Letchumanan, R. ve Kodama, F. (2000). Reconciling the Conflict between The 'Pollution Havens' Hypothesis and an Emerging Trajectory of International Technology Transfer. Research Policy, 29, 59-79.

Linh, D. H. ve Lin, S. (2014). CO2 Emissions, Energy Consumption, Economic Growth and FDI in Vietnam. Managing Global Transitions, 12(3), 219-232.

List, J. A. ve Co, C. Y. (2000). The Effect of Environmental Regulation on Foreign Direct Investment. Journal of Environmental Economics and Management, 40, 1-20.

Magazzino, C. (2016). The Relationship between Real GDP, CO2 Emissions, and Energy Use in The GCC Countries: A Time Series Approach. Cogent Economics \& Finance, 4(1), 1-20.

Managi, S. ve Pradyot, R. J. (2008). Environmental Productivity and Kuznets Curve in India. Ecological Economics, 65, 432 - 440.

Masih, A. M. M. ve Masih, R. (1996). Energy Consumption, Real Income and Temporal Causality: Results from A Multi-country Study Based on CoIntegration and Error-Correction Modeling Techniques. Energy Economics, $18,165-183$.

Narayan, P. K. ve Narayan, S. (2010). Carbon Dioxide Emissions and Economic Growth: Panel Data Evidence from Developing Countries. Energy Policy, 38(1), 661-666.

Narayan, P. K. ve Smyth, R. (2007). Energy Consumption and Real GDP in G7 Countries: New Evidence from Panel Co-integration with Structural Breaks. Energy Economics, 30, 2331-2341.

Osabuohien E. S., Efobi U. R. ve Gitau C. M. (2004). Beyond the Environmental Kuznets Curve in Africa: Evidence from Panel Cointegration. Journal of Environmental Policy and Planning, 16(4), 517-538.

Özel, H. A., ve Sezgin, F. (2012). Ticari Serbestleşme-Ekonomik Büyüme İlişkisinin Bootstrap Kantil Regresyon Yardımıyla Analizi. İstanbul Üniversitesi Iktisat Fakültesi Mecmuası, 62(2), 283-303. 
Özokçu, S. ve Özdemir, Ö. (2017). Economic Growth, Energy and Environmental Kuznets Curve. Renewable and Sustainable Energy Reviews, 72, 639-647.

Öztürk, İ. ve Acaravc1, A. (2010). CO2 Emissions, Energy Consumption and Economic Growth in Turkey. Renewable and Sustainable Energy Reviews, 14, 3220-3225.

Öztürk, Z. ve Öz, D. (2016). The Relationship between Energy Consumption, Income, Foreign Direct Investment, and CO2 Emissions: The Case of Turkey. Çankırı Karatekin Üniversitesi İ̈BF Dergisi, 6(2), 269-288.

Pao, H. ve Tsai, C. (2011). Multivariate Granger Causality between CO2 Emissions, Energy Consumption, FDI (Foreign Direct Investment) and GDP (Gross Domestic Product): Evidence from a Panel Of BRIC (Brazil, Russian Federation, India, And China) Countries. Energy, 36, 685-693.

Paul, S. ve Bhattacharya, R. N. (2004). Causality between Energy Consumption and Economic Growth in India: A Note on Conflicting Results. Energy Economics, 26, 977-983.

Pearl, J. (1995). Causal Diagrams for Empirical Research, Biometrika, 82(4), 669688.

Pesaran, M. H., Shin, Y. ve Smith R. J. (2001). Bounds Testing Approaches to the Analysis ff Level Relationships. Journal of Applied Econometrics, 16(3), 289326.

Porter, M. E. ve van der Linde, C. (1995). Towards a New Conception of the Environmental-Competitiveness Relationship. Journal of Economic Perspective, 9, 97-118.

Richmond, A. K. ve Kaufmann, R. K. (2006). Is There a Turning Point in the Relationship between Income and Energy Use and/or Carbon Emissions? Ecological Economics, 56(2), 176-189.

Roberts, J. T. ve Grimes, P. E. (1997). Carbon Intensity and Economic Development 1962-91: A Brief Exploration of the Environmental Kuznets Curve. World Development, 25(2), 191-8.

Saboori, B., Sulaiman, J. ve Mohammed, S. (2012). Economic Growth and CO2 Emissions in Malaysia: A Cointegration Analysis of the Environmental Kuznets Curve. Energy Policy, 51, 184-191.

Saboori, B. ve Sulaiman, J. (2013). Environmental Degradation, Economic Growth and Energy Consumption: Evidence of the Environmental Kuznets Curve in Malaysia. Energy Policy, 60, 892-905.

Saidi, K. ve Hammami, S. (2015). The Impact of Energy Consumption and CO2 Emissions on Economic Growth: Fresh Evidence from Dynamic Simultaneous-Equations Models. Sustainable Cities and Society, 14, 178-186. 
Salahuddin, M. ve Gow, J. (2014). Economic Growth, Energy Consumption and $\mathrm{CO} 2$ Emissions in Gulf Cooperation Council Countries. Energy, 73, 44-58.

Selden, T. ve Song, D. (1994). Environmental Quality and Development: Is There a Kuznets Curve for Air Pollution Emissions? Journal of Environmental Economics and Management, 27, 147-162.

Shahbaz, M., Zeshan, M. and Afza, T. (2012). Is Energy Consumption Effective to Spur Economic Growth in Pakistan? New Evidence from Bounds Test to Level Relationships and Granger Causality Tests. Economic Modeling, 29(6), 2310-2319.

Soytaş, U. ve Sarı, R. (2003). Energy Consumption and GDP: Causality Relationship in G-7 And Emerging Markets. Energy Economics, 25, 33-37.

Soytaş, U. ve Sarı, R. (2006). Energy Consumption and Income in G7 Countries. Journal of Policy Modeling, 28, 739-750.

Soytaş, U. ve Sarı, R. (2009). Energy Consumption, Economic Growth, and Carbon Emissions: Callenges Faced by an EU Candidate Member. Ecological Economics, 68, 667-75.

Spirtes, P., Glymour, C. ve Scheines, R. (2000). Causation, Prediction, and Search. Second Edition, Cambridge, MA: MIT Press.

Squalli, J. (2007). Electricity Consumption and Economic Growth: Bounds and Causality Analysis of OPEC Members. Energy Economics, 29(6), 1192-1205.

Stern, D. I. (1993). Energy and Economic Growth in The USA: A Multivariate Approach. Energy Economics, 15, 137-150.

Stern, D. I. (2000). A Multivariate Co-integration Analysis of the Role of Energy in the US Macroeconomy. Energy Economics, 22, 267-283.

Suri, V. ve Chapman, D. (1998). Economic Growth, Trade and Energy: Implications for the Environmental Kuznets Curve. Ecological Economics, 25, 195-208.

Şeker, F., Ertuğrul, H. M., ve Çetin, M. (2015). The Impact of Foreign Direct Investment on Environmental Quality: A Bounds Testing and Causality Analysis for Turkey. Renewable and Sustainable Energy Reviews, 52, 347356.

Tang, C. F. ve Tan, B. W. (2015). The Impact of Energy Consumption, Income and Foreign Direct Investment on Carbon Dioxide Emissions In Vietnam. Energy, 79, 447-454.

Topallı, N. (2016). Doğrudan Sermaye Yatırımları, Ticari Dışa Açıklık ve Ekonomik Büyüme Arasındaki İlişki: Türkiye ve BRICS Ülkeleri Örneği. Dogus University Journal, 17(1), 83-95. 
Tsani, S. Z. (2010). Energy Consumption and Economic Growth: A Causality Analysis for Greece. Energy Economics, 32(3), 582-590.

UNCTAD (2018). World Investment Report. http://unctad.org/en/PublicationsLibrary/wir2018_en.pdf (Erişim: 10.01.2020)

UNCTAD (2019) World Investment Report. http://unctad.org/en/PublicationsLibrary/wir2019_en.pdf (Erişim: 10.01.2020)

Üzar, U. (2019). Doğrudan Yabancı Yatırım, Büyüme ve Çevresel Kalite İlişsisi: Türkiye "Dibe Yarışan" Bir Ülke mi?. Mehmet Akif Ersoy Üniversitesi İktisadi ve İdari Bilimler Fakültesi Dergisi, 6(2), 439-451.

Üzar, U. ve Eyuboğlu, K. (2019). Is Foreign Direct Investment an Engine for Energy Consumption? An Empirical Investigation for Turkey. Environmental Science and Pollution Research, 26(27), 28092-28105.

Van Beers, C. ve van den Bergh J. M. (1997). An Empirical Multi-Country Analysis of the Impact of Environmental Regulations on Foreign Trade Flows. Kyklos, 50, 29-46.

Verma, T. S. ve Pearl, J. (1990). Causal Networks: Semantics and Expressiveness. Machine Intelligence and Pattern Recognition, 9, 69-76.

Wang, S., Li, Q., Fang, C. ve Zhou, C. (2016). The Relationship between Economic Growth, Energy Consumption, and CO2 Emissions: Empirical Evidence from China. Science of the Total Environment, 542, Part A: 360 371.

Yang, J., Guo, H., ve Wang, Z. (2006). International Transmission of Inflation Among G-7 Countries: A Data-Determined VAR Analysis. Journal of Banking \& Finance, 30(10), 2681-2700.

Yu, E. S. H. ve Choi, J. Y. (1985). The Causal Relationship between Energy and GNP: An International Comparison. Journal of Energy and Development, 10, 249-272.

Yuan, J., Kang, J., Zhao, C. ve Hu, Z. (2008). Energy Consumption and Economic Growth: Evidence from China at Both Aggregated and Disaggregated Levels. Energy Economics, 30, 3077-3094.

Zanin, L. ve Marra, G. (2012). Assessing the Functional Relationship between CO2 Emissions and Economic Development Using an Additive Mixed Model Approach. Economic Modelling, 29(4), 1328-1337.

Zarnikau, J. (1997). A Reexamination of the Causal Relationship between Energy Consumption and Gross National Product. Journal of Energy and Development, 21, 229-239. 
Zhang, J., Bessler, D. A. ve Leatham, D. J. (2006). Does Consumer Debt Cause Economic Recession? Evidence Using Directed Acyclic Graphs. Applied Economics Letters, 13(7), 401-407.

Zhang, X-P. ve Cheng, X-M. (2009). Energy Consumption, Carbon Emissions, and Economic Growth in China. Ecological Economics, 68, 2706-2712. 